Relations industrielles

Industrial Relations

\title{
Report 10: Measurement of Physical Output at the Job Level, by Einar HARDIN, July 1951, 13 pp., Price: \$1.00.
}

\section{Emile Gosselin}

Volume 8, numéro 4, septembre 1953

URI : https://id.erudit.org/iderudit/1022937ar

DOI : https://doi.org/10.7202/1022937ar

Aller au sommaire du numéro

Éditeur(s)

Département des relations industrielles de l’Université Laval

ISSN

0034-379X (imprimé)

1703-8138 (numérique)

Découvrir la revue

Citer ce compte rendu

Gosselin, E. (1953). Compte rendu de [Report 10: Measurement of Physical

Output at the Job Level, by Einar HARDIN, July 1951, 13 pp., Price: \$1.00.]

Relations industrielles / Industrial Relations, 8(4), 414-414.

https://doi.org/10.7202/1022937ar

Tous droits réservés (C Département des relations industrielles de l’Université Laval, 1953
Ce document est protégé par la loi sur le droit d'auteur. L’utilisation des services d'Érudit (y compris la reproduction) est assujettie à sa politique d'utilisation que vous pouvez consulter en ligne.

https://apropos.erudit.org/fr/usagers/politique-dutilisation/ 
Loss Positions of an Individual Firm?", are dealt with. The problem of whether a plan should be contributory, the actuarials aspects of such plans are also discussed. The Report ends by a discussion of "Profit Sharing: LaborManagement Cooperation in Free Enterprise".

R. C.

Report 8: How to Build a Merchandise Knowledge Test by JosEPHINE S. Welch and C. Harold Stone, July 1951,21 pp. $\$ 1.00$.

This manual, based on recent research experience of the Center for the development of three Merchandise Knowledge tests to be used in department stores, presents step-by-step useful methods for the preparation of such tests. Merchandise Knowledge tests can be used effectively in the selection process to differentiate between applicants with varying degrees of experience. They may also be valuable for esetablishing equitable bases for transfers and promotions, for checking adequacy of the training and educational program and for guiding in differential training of newly hired employees. This bulletin is to be recommended to every department store wishing to reduce turnover and increase sales efficiency.

\section{R. C.}

Report 9: Job Evaluation Practices, Proceedings of a Conference, July 1951, 67 pp. Price $\$ 1.00$.

The use of job evaluation techniques is now widespread in industry. This Report stands half-way between the specialized books on the subject and the comprehensive Personnel Administration Hand books, with less technical detail than the former and a much more elaborate discussion than the latter. Within a few pages, the reader learns sufficiently about Job Evaluation, its history, purposes, basic systems, application to various types of personnel or firm and limitations, to be able at the end to make his own judgment on it. The reading of William Gomberg's article, "Joint Union-Management Evaluation" should prove of value to the critical minds.

R. C.

Report 10: Measurement of Physical Output at the Job Level, by EnNAR Hardin, July 1951, 13 pp., Price: $\$ 1.00$.

Le problème de la Productivité soulève un intérêt toujours croissant dans le monde patronal et ouvrier, surtout lorsque les discussions portent sur le salaire. Il n'est cependant pas toujours facile de s'entendre sur le concept même de la Productivité, et nombre de controverses s'élèvent lorsqu'il s'agit de mesurer la production du travailleur à l'aide de méthodes éprouvées. Le Centre des Relations Industrielles de l'Université de Minnesota s'efforce d'éclairer ces divers problèmes en présentant une étude technique fortement documentée sur la façon de mesurer la production du travailleur à l'aide de méthodes éprouvées.

Après avoir défini ce qu'il faut entendre par production physique, Einar Hardin, l'auteur du rapport, souligne les avantages que patrons et travailleurs retirent lorsqu'on s'emploie à mesurer la production d'un travailleur ou d'un groupe de travailleurs. Entre autres avantages, une telle mesure permet une meilleure rationalisation de la production, facilite la comptabilité du salaire et fournit des bases solides pour la fixation et l'ajustement des salaires. Il faudra procéder avec beaucoup de précautions dans l'établissement d'un tel programme, car les méthodes utilisées pourront varier selon l'objet poursuivi. Quelle tâche doit-on mesurer? Comment en préciser le con+enu? Quelle période de temps faut-il adopter pour mesurer la production physique d'un employé? Doit-on adopter une méthode directe ou indirecte pour mesurer cette production? Quelles méthodes d'échantillonnage faut-il u'iliser? Ce sont là des problèmes que l'aut'eur analyse avec beaucoup de nuances, dans un langage parfois assez technique, mais à la portée de tous ceux qui s'intéressent activement à la mesure de la productivité du travail.

E. G. 